\title{
The Effect Of Transcutaneous Electrical Nerve Stimulation (Tens) Towards Pain Level Of Patients With Diabetes Mellitus (Dm) With Peripheral Neuropathy In Diabetic Foot Ulcer Treatment In Yogyakarta General Hospital Indonesia
}

\author{
Mr. Satriya Pranata ${ }^{1}$, Dr. K Heri Nugroho $\mathrm{HS}^{2}$, Dr. Untung Sujianto ${ }^{3}$ \\ ${ }^{1}$ (Students of Master of Nursing at Diponegoro University- Indonesia) \\ ${ }^{2}$ (Lecturer of the Master of Nursing and Medical Studies Program at Diponegoro University Indonesia) \\ ${ }^{3}$ (Lecturer of the Master of Nursing at Diponegoro University Indonesia)
}

\begin{abstract}
:
Study Objective: Pain is a sensory and emotional experience shown by the patient as a response to the damage of the skin tissue or muscle. In fact, it is usually found that diabetic patients who experience pain during wound care treatment can not be handled properly. The purpose of this study is to find out the effect of TENS intervention towards the level of pain in DM patients with peripheral neuropathy in diabetic foot ulcer treatment.

Design: Random control trial ( $R C T)$

Method and Measurements: 28 respondents which were divided into 14 interventions and 14 control groups. Respondents' pain was assessed before and after the intervention of TENS for 15 minutes with the electrical frequency of $100 \mathrm{~Hz}$ using Numeric Rating Scale tools. Statistic test: statistical test was conducted using independent $T$ test and Paired $T$ test.

Results: There is a difference in the level of pain in the intervention group and control groups with $P=0.000$. Intervention of TENS for 15 minutes with a frequency of $100 \mathrm{~Hz}$ effectively reduces the pain level of the patients with diabetes mellitus with with peripheral neuropathy in diabetic foot ulcer treatment is done with a $P$ value of $<0.05$.

Conclusions: TENS effectively reduces pain in diabetic patients with peripheral neuropathy in diabetic foot ulcer treatment.
\end{abstract}

Keywords: TENS, Diabetes Mellitus, Pain, Wound Care

\section{Introduction}

The total of DM patients around the world are 387 million people (8.3\%), the DM patients who died in 2014 were 4.9 million people ${ }^{(1)}$. The patients with DM in Indonesia in 2014 were 9.1 million $(5.81 \%)$. Meanwhile, undiagnosed DM patients with diabetes were 4.8 million (5.27\%), and patients who died because of the DM were 175.836 people (1.9\%), it is predicted that the number of Indonesian population who will be suffered from diabetes in 2035 are about 14.1 million ${ }^{(1)}$. There are $60-70 \%$ of people with diabetes experience diabetic peripheral neuropathy and $\mathrm{DM}^{(2)}$. Diabetic peripheral neuropathy disorders result in communication stimulation signal barriers in the body, it causes patient's impaired sensation and having dry skin as sweat glands under the skin is reduced. Sensation disruption will cause pain transmission to the brain to sensitize people of the dangers in the foot like a nail punctured or exposed to hot objects becomes subside, this condition results diabetic ulcers occur in the foot.

Intervention which is routinely performed on diabetic foot ulcer is a wound treatment. When the nurse treats patient's wound, often the patient gives complain of pain ${ }^{(3)}$. In fact, it shows that diabetic patients who experience pain during wound care are not treated properly. The pain that is not handled properly will affect the patient's psychological responses such as uncooperative patients during the treatment and it makes the wound healing process is running slow ${ }^{(3-6)}$.

The provision of anti-pain drugs often causes addiction. Deep breathing intervention, biofeedback and progressive muscle relaxation are sometimes not able to cope with pain in diabetic patients with diabetic ulcer while then wound care is conducted since the patients feel the pain on a scale of moderate to severe. The previous theories, studies and Nursing Intervention Classification (NIC) suggest that intervention of transcutaneous electrical nervous stimulation (TENS) is able to reduce the pain. TENS is a device that produces an electric current to stimulate nerves to reduce the pain, the unit of tool is equipped with electrodes to deliver electrical current that will stimulate the nerves in the area of pain ${ }^{(7,8)}$. It also can reduce acute and chronic pain (9-11). TENS with a frequency of $100 \mathrm{hz}$ and is given for an hour can reduce post-operative pain in cardiac 
surgery and may improve lung function ${ }^{(9)}$. TENS with a frequency of $80 \mathrm{~Hz}$ and is given for $15-20$ minutes can reduce pain in patients with post partum ${ }^{(11,12)}$.

In addition to standard pharmacological therapy undertaken by hospitals to reduce pain in diabetic patients who get wound treatment, patients also need to acquire complementary therapies such as TENS to overcome the pain. Aim To find out the effect of TENS towards pain levels of the patients with type 2 diabetes mellitus with peripheral neuropathy in diabetic foot ulcers treatment.

\section{Material And Method}

The method used is Random Control Trial with single blind. This study was conducted from May to July 2016 in Yogyakarta General Hospital Indonesia. There are 28 respondents in the study with 14 interventions and 14 control groups. In this study, the sample used is a sample that met the inclusion criteria and exclusion samples. The inclusion criterias in this study are; not taking psychotic drugs during the research was being conducted, not experiencing any loss of consciousness, experiencing moderate pain scale (4-6) when the wound was treated, not consuming anti-pain medication before the intervention of TENS, patients with DM ulcer on the lower extremities, and in the stage 1 and 2 of DM ulcers. Exclusion criterias in this study are; DM patients who have other diseases such as epilepsy, the patients are not attached to electrodes connected to cardiac monitoring.

Research tool used in this study were respondent characteristics questionnaire, TENS used as an additional intervention when diabetic foot ulcers treatment was conducted, Numeric Rating Scale (NRS) to measure the level of pain, and standard wound treatment procedures. The product name of TENS is Beurer Digital TENS with a frequency range of 1-250 Hz.

Before the study was conducted, researchers submitted a written request to the director of the Yogyakarta General Hospital. Furthermore, socialization was carried out explained the goals, objectives of the research and procedures of research to ward chief, the nursing staff and doctors in charge of patients.

Researchers selected patients diagnosed with diabetes mellitus with peripheral neuropathy based on medical records and determination of peripheral neuropathy using tests of Doulour Neuropathi 4 (DN4). Once a patient is included in the inclusion criteria, the researchers then asked the prospective respondent's willingness to participate after receiving an explanation of the purpose, objectives, benefits, research procedure, and the rights and obligations of the respondents. For those respondents who were willing to be part of the research, researchers further requested the prospective respondents to sign the inform concern sheet. Furthermore, randomly the respondents were determined whether they were included the intervention group or the control group.

The intervention group got first session of TENS interventions for 15 minutes once, followed by second session on the next day with the same duration and frequency. Electrodes of TENS tools placed in the path which the nerve pain around the wound with a frequency of $100 \mathrm{~Hz}$. The pain of respondents in the intervention group or a control group was measured by asking respondents to express their pain by marking the sign using ballpoint on the NRS. The pain was measured using the NRS performed on pre and post intervention. The measurement of post intervention pain was conducted in two sessions.

Distribution of respondents by sex, age, ethnicity, employment, period of suffering from diabetes, frequency of ulcers occurrence, period of ulcers experience, the value of ABI and anxiety. (Table 1 and Table 2)

Table 1. Characteristics of Respondents by Gender, Ethnicity and Employment

\begin{tabular}{|c|c|c|c|c|c|}
\hline \multirow[t]{2}{*}{ Variable } & \multicolumn{2}{|c|}{ Intervension } & \multicolumn{2}{|c|}{ Control } & \multirow[t]{2}{*}{ Total (\%) } \\
\hline & $\mathrm{N}$ & $\%$ & $\mathrm{~N}$ & $\%$ & \\
\hline \multicolumn{6}{|l|}{ Sex } \\
\hline - Male & 7 & 50 & 5 & 35,7 & $12(42,86)$ \\
\hline - $\quad$ Female & 7 & 50 & 9 & 64,3 & $16(57,14)$ \\
\hline \multicolumn{6}{|l|}{ Ethnicity } \\
\hline - Javanese & 14 & 100 & 14 & 100 & $28(100)$ \\
\hline - $\quad$ Non Javanese & 0 & 0 & 0 & 0 & $0(0)$ \\
\hline \multicolumn{6}{|l|}{ Employment } \\
\hline - Labor & 3 & 21,4 & 3 & 21,4 & $6(21,43)$ \\
\hline - $\quad$ Housewife & 3 & 21,4 & 5 & 35,7 & $8(28,57)$ \\
\hline - $\quad$ Civil Servant Pensionary & 1 & 7,1 & 0 & 0 & $1(3,57)$ \\
\hline - $\quad$ Civil Servant & 2 & 14,5 & 1 & 7,1 & $3(10,72)$ \\
\hline Driver & 1 & 7,1 & 0 & 0 & $1(3,57)$ \\
\hline - $\quad$ Enterpreneur & 3 & 21,4 & 2 & 14,3 & $5(17,86)$ \\
\hline - $\quad$ Pedicab Driver & 1 & 7,1 & 0 & 0 & $1(3,57)$ \\
\hline - Scavenger & 0 & 0 & 2 & 14,3 & $2(7,14)$ \\
\hline Farmer & 0 & 0 & 1 & 7,1 & $1(3,57)$ \\
\hline
\end{tabular}


Table 2. Characteristics of Respondents by Age, Period of Suffering from diabetes, ABI value and Anxiety

\begin{tabular}{|l|l|l|l|}
\hline Variable & & Intervension & Control \\
\hline Age & Mean & 54,79 & 54,43 \\
& Median & 56,00 & 53,50 \\
& SD & 8,239 & 7,187 \\
& Min-Max & $32-67$ & $39-64$ \\
& $95 \%$ CI & $50,03-59,54$ & $50,62-56,58$ \\
\hline Period of suffering & Mean & 7,29 & 3,93 \\
from diabetes & Median & 4,50 & 3,00 \\
& SD & 6,966 & 3,025 \\
& Min-Max & $1-20$ & $1-11$ \\
& $95 \%$ CI & $3,26-11,31$ & $3,46-7,76$ \\
\hline Value of ABI & Mean & 0,84 & 0,84 \\
& Median & 0,84 & 0,85 \\
& SD & 0,03916 & 0,04413 \\
& Min-Max & $0,61-0,90$ & $0,60-0,90$ \\
& $95 \%$ CI & $0,81-0,86$ & $0,82-0,85$ \\
\hline Anxiety & Mean & 14,64 & 16,00 \\
& Median & 13,50 & 16,00 \\
& SD & 6,924 & 6,312 \\
& Min-Max & $4-28$ & $7-29$ \\
& $95 \%$ CI & $10,65-18,64$ & $12,79-17,86$ \\
\hline
\end{tabular}

The frequency distribution of respondents' level of pain before and after the intervention of TENS on the first day and second day. (Table 3)

Table 3. Distribution of respondents by Pain Levels Before and After Intervention of TENS

\begin{tabular}{|l|l|l|l|l|l|l|}
\hline & Intervension & Post 1 & Post 2 & Pre & Post 1 & Post 2 \\
\cline { 2 - 7 } & Pre & 3,14 & 2,79 & 2,43 & 5,29 & 4,86 \\
Mean & 2,64 & 3,00 & 3,00 & 3,00 & 5,50 & 5,00 \\
Median & 3,00 & 0,535 & 0,579 & 1,089 & 0,825 & 0,864 \\
SD & 1,008 & $2-4$ & $2-4$ & $1-4$ & $4-6$ & $4-6$ \\
Min-Max & $1-4$ & $2,83-3,45$ & $2,45-3,12$ & $1,80-3,06$ & $4,81-5,76$ & $4,36-5,36$ \\
95\% CI & $2,06-3,22$ & \multicolumn{5}{|l}{} \\
\hline
\end{tabular}

Table 4 shows the analysis result of different pain levels test before and after the intervention in intervention group and control group

Table 4. Analysis Test Result of Different Pain Level Before and After TENS Intervention

\begin{tabular}{|l|l|l|l|l|l|}
\hline Variable & Group & $\mathrm{n}$ & Mean Rank & Sum of Ranks & Pvalue \\
\hline Pain Level before & Control Group & 14 & 13,79 & 193,00 & 0.631 \\
intervension & Intervension Group & 14 & 15,21 & 213,00 & \\
\hline Pain Level after & Control Group & 14 & 21,18 & 296,50 & 0.000 \\
intervension Day 1 & Intervension Group & 14 & 7,82 & 109,50 & \\
\hline Pain Level after & Control Group & 14 & 21,29 & 298,00 & 0.000 \\
intervension Day 2 & Intervension Group & 14 & 7,71 & 108,00 & \\
\hline
\end{tabular}

Table 5 shows the results of TENS intervention effect test analysis on the level of pain before and after intervention in intervention group and control group

Table 5. Analysis Test Results of TENS Effect On the Level of the Pain

\begin{tabular}{|l|l|l|l|l|l|l|}
\hline Variable & Group & Mean & SD & N & CI 95\% & p-value \\
\hline Pain Level & Intervension & & & 14 & & \\
& Before & 2,64 & 1,008 & & $2,06-3,22$ & \\
& After intervension Day1 & 3,14 & 0,535 & & $2,83-3,45$ & 0,052 \\
& After intervension Day 2 & 2,79 & 0,579 & & $2,45-3,12$ & 0,025 \\
\cline { 2 - 7 } & Control & & & 14 & & \\
& Before & 2,43 & 1,089 & & $1,80-3,06$ & \\
& After intervension Day1 & 5,29 & 0,825 & & $4,81-5,76$ & 0,092 \\
& After intervension Day 2 & 4,86 & 0,864 & & $4,36-5,36$ & 0,084 \\
\hline
\end{tabular}

\section{Discussion}

The results show that there are no differences in response to pain in the intervention group and the control group before the intervention TENS with a $\mathrm{P}$ value of 0.631 ( $\mathrm{P}$ value> 0.05). Meanwhile, there are differences in response to pain in the intervention group and the control group after the intervention of TENS. The average response to pain in the intervention group after wound treatment and given first TENS treatment on the first day is 3.14 (mild pain), then after wound treatment and TENS treatment given on the second day, the 
average pain patients is 2.79 (mild pain). Meanwhile, in the control group, the pain score is 5.29 (moderate) on the first day, while in the second day the average pain score is 4.84 (moderate pain). From statistical test results , it is obtained the $\mathrm{P}$ value of 0.000 ( $\mathrm{P}$ value $<0.05$ ). It can be concluded that there is a significant difference level of pain after the treatment in the intervention group and the control group.

The results of this study are supported by research conducted by Gardner (2013) which states that the patients included in the intervention group have lower pain levels (different) than the control group with $\mathrm{P}$ Value 0.000 (pvalue $<0.05$ ) when the wound treatment was carried out of ${ }^{(13)}$. In the intervention group and the control group there were significant differences in terms of dependence on pain-lowering drugs with a $\mathrm{P}$ value of 0.002

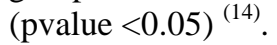

The same characteristics of pain before wound treatment in this study occur due to the time when the wound did not get any treatments, and parts of the body which are injured did not get any stimulation. This is what causes the pain scale perceived by respondent is not different ${ }^{(3)}$. While the differences in levels of pain after wound treatment occur because the intervention group received TENS interventions. TENS tool will deliver the electrical signal so that the signal interferes the pain impulse. Tingling is good distraction so that the pain can be decreased and the intervention may work well when the wound treatment is being carried out.

Pain is the most common cause for someone to perform self-treatment and seek medical help at the health care system ${ }^{(15)}$. The pain is unpleasant sensory and emotional experience as a result of actual or potential tissue damage ${ }^{(2)}$. The systems involved in the pain transmission and sensation is called nociceptive system. The sensitivity of the nociceptive system components can be influenced by a number of factors and may vary among individuals.

Not all people exposed to the same stimulus experience the same pain intensity. A very painful sensation is for someone can be very painless for others. Furthermore, a stimulus may result in pain at one time but not at other times. These factors can decrease or increase the sensitivity of different components.

Pain receptors (nociceptors) are free nerve endings in the skin that respond only to the strong stimulus which is potentially damaging. The stimulus are mechanical, thermal, and chemical. Joints, skeletal muscle, fascia, tendons and corneas also have pain receptors which have the potential to transfer stimulus that causes pain. Pain receptors are complex multidirectional pathways.

These nerve fibers branch very close to the origin in the skin and sends branches to the local blood vessels, mast cells, hair follicles and sweat glands. The fibers of pain receptors in the skin will cause visceral relationship of the same fibers, and vice versa. Strong stimulation on visceral branch fibers can lead to vasodilation and pain in the area of the body associated with the fibers ${ }^{(2)}$.

A number of substances that affect the sensitivity of nerve endings or pain receptors are released into the extracellular tissue as a result of tissue damage. Chemical substances that increase pain transmission or perception include histamine, bradykinin, acetylcholine and $\mathrm{p}$ substance. Prostaglandin is chemical substance which can increase the sensitivity of pain receptors by enhancing the effects that causes bradykinin pain ${ }^{(2)}$.

The existence of endorphin and ensefalin can explain the different responses of the pain felt by someone. People who have a lot of endorphin and ensefalin will feel lighter pain response compared to individuals who have less levels of endorphins and ensefalin ${ }^{(2)}$.

Descendens path which modulates pain may block pain signal that is from the level of the spinal cord. Besides, neurons containing endorphin in periakuaduktus grisea substance and gelatinous substance actively play role in the modulation of pain. Perception is final result of the pain mechanism process. Pain impulses are transmitted and causing subjective feelings of pain itself. Overall, the quality of different pain experience is the activity of projection path of multiple paraller ascending from the spinal cord to the midbrain, forebrain, and cerebral cortex $^{(2)}$.

Patients with type 2 diabetes mellitus (DMT2) were given TENS intervention for two days for 15 minutes with a frequency of $100 \mathrm{~Hz}$ and effectively lower the patient's pain on the second day with a $\mathrm{P}$ value of 0.025 (P value <0.05). The result of this study is consistent with research conducted by Noehren (2015) which states that the intervention of TENS to patients with fibromyalgia can reduce the pain and improve the quality of patients's life ${ }^{(11)}$. TENS is not invasive and it has no pharmacological effect in pain relief ${ }^{(16)}$. Moreover, TENS is proven to reduce uterine contractions in the case of post-partum patients before giving breast feeding ${ }^{(17)}$. TENS intervention which is given to post episiotomy patients will make patients' wound healed as the edema is reduced, it also effectively can lower the pain and improve ambulation of patients faster. In fact, TENS is proven effective to reduce chronic pain such as low back pain ${ }^{(18)}$.

In this research, the frequency of electricity current supplied through TENS to the patients is $100 \mathrm{~Hz}$ because during the time when the pilot project was conducted, the patients with type 2 diabetes who have peripheral neuropathy did not immediately notice the comfort sensation at frequencies below $100 \mathrm{~Hz}$ electricity when their wound were treated. The TENS intervention above $100 \mathrm{~Hz}$ was not given because previous research study says that giving the electrical frequencies above $125 \mathrm{~Hz}$ will result in a risk of burns although with less harmful effects ${ }^{(19)}$. In terms of the condition of patients with type 2 diabetes who have neuropathy, the 
characteristics of the wound was hot so if TENS intervention is given above $100 \mathrm{~Hz}$ it will worsen the patient's wound (burns).

TENS intervention mechanism in reducing pain level for patients with type 2 diabetes with peripheral neuropathy whose the foot ulcers treated works closely with the electric current generated by the TENS tool then channeled through electrodes placed on the nerves that innervate the wound. The tingling sensation under the skin and muscle are forms of distraction perceived by the patients and TENS in the form of electrical signals would interfere pain signal that affects the nerves and break the signal so that the patient will feel pain is reduced. Signal termination process is supported by the theory of pain gates by activating A beta perpheral in the dorsal horn area that modulates A delta and $\mathrm{C}$ fibers that conduct pain so that pain is blocked. In addition to blocking the nerves that innervate the area of pain, electrical stimulation is also able to help the body to produce natural painkillers called endorphins so that patients become more relaxed ${ }^{(19)}$.

Researchers believe that the TENS intervention gives a significant effect in reducing pain in patients who underwent the treatment of diabetic foot ulcers with peripheral neuropathy for several reasons, including randomization of this research, measurement which was conducted before and after the intervention group and the control group, confounding variables such as anxiety, as well as the value of ABI and pain level before the intervention between the intervention and control groups are similar (homogeneous). The advantage of the use of TENS while the research was conducted is that patients are not addictive, does not cause drowsiness, nausea, and can be given at any time without any additional side effects.

\section{Conclusion}

TENS intervention that has been given do not cause side effects such as addiction, drowsiness, nausea, and can be given at any time without any additional side effects. There are differences in the level of pain in patients with type 2 diabetes mellitus with peripheral neuropathy who get the treatment of diabetic foot ulcers in the intervention group and the control group. TENS gives contribution to the reduction of the pain in patients with type 2 diabetes with peripheral neuropathy who has DM foot ulcer treatment.

\section{References}

[1]. IDF. Panduan Global Untuk Diabetes Tipe 2. 2014; Available from: www.idf.org.communication@idf.org

[2]. Brunner and Suddarth. Keperawatan Medikal Bedah Edisi 8 Volume 2. Jakarta: Penerbit Buku Kedokteran EGC. 2001;

[3]. Kristianto H. Perbandingan Perawatan Luka Tekhnik Modern dan Konventional Terhadap Transforming Growth Factor Beta 1 dan Respon Nyeri Pada Luka Diabetes Melitus. Tesis dipublikasikan. Jakarta: FIK Program Magister Ilmu Keperawatan. $2010 ; 1$.

[4]. International Association for the Study of Pain 2009 Annual Report $®$ 1. 2009;

[5]. R W. Pain assessment and management in patients with chronic wounds. Nurs Stand. 2008;22(32):62-8

[6]. Kehlet H. Acute pain control and accelerated postoperative surgical recovery. Surg Clin North Am [Internet]. 1999 Apr;79(2):43143. Available from: http://search.ebscohost.com/login.aspx?direct=true \&db=mnh\&AN=10352662\&site=ehost-live \&scope=site

[7]. Tucker SM, Canobbio MM PE\& W. Standar Perawatan Pasien:Proses Keperawatan, Diagnosis dan Evaluasi, Edisi 5. Jakarta: Penerbit Buku Kedokteran EGC. 2008;5.

[8]. James J BC\& SH. Prinsip-Prinsip Sains untuk Keperawatan, EMS. Jakarta. 2008;

[9]. Galli TT, Chiavegato LD, Santiago NR, Liebano RE. Effects of transcutaneous electrical nerve stimulation on pain , walking function, respiratory muscle strength and vital capacity in kidney donors : a protocol of a randomized controlled trial. 2013;

[10]. Santuzzi CH, Azevedo H De, Neto F, Guilherme J, Pires P, Luiz W, et al. High-frequency transcutaneous electrical nerve stimulation reduces pain and cardio-respiratory parameters in an animal model of acute pain : Participation of peripheral serotonin. 2013;29(8):630-8.

[11]. Noehren B, Dailey DL, Rakel BA, Vance CGT, Zimmerman MB, Crofford LJ, et al. Brian Noehren, Dana L. Dailey, Barbara A. Rakel, Carol G.T. Vance, Miriam B. Zimmerman, Leslie J. Crofford, Kathleen A. Sluka. 2015;

[12]. Spank, J.T, Cambier DC, De Paepe HM, Danneels LA, Witvrouw EE BL. Pain relief in labour by transcutaneous electrical nerve stimulation (TENS). Arch Gynecol Obstet. 2000;264:131-6.

[13]. Gardner SE , Blodgett NP HS. HI-TENS reduces moderate-to-severe pain associated with most wound care procedures: a pilot study. Biological Research For Nursing [Biol Res Nurs]. 2014;16(3):pp. 310-9.

[14]. JM B. Transcutaneous electrical nerve stimulation (TENS) can reduce postoperative analgesic consumption. A meta-analysis with assessment of optimal treatment parameters for postoperative pain. European Journal Of Pain (London, England) [Eur J Pain]. 2003;7(2):pp. 181-8.

[15]. Eccleston C. Role of psychology in pain management. 2001;87(1):144-52.

[16]. Jaafarpour. The Analgesic Effect of Transcutaneous Electrical Nerve Stimulation (TENS) on Caesarean Under Spinal Anaesthesia. Journal of Clinical and Diagnostic Research. 2008;

[17]. Sousa L De, Gomes-sponholz FA, Nakano AMS. Transcutaneous electrical nerve stimulation for the relief of post-partum uterine contraction pain during breast-feeding: A randomized clinical trial. 2014;40(5):1317-23.

[18]. Alyazedi FM, Khan S, Al AH, Al-toriri N, Shamsi S. Effect of Ultrasound and Exercise together and TENS alone in the Management of Chronic back pain. 2015;4(5):110-4.

[19]. Johnson M. electrical nerve stimulation ( TENS ). :259-86. 